\title{
Research on the Training Mode of Automotive Applied Talents Hongwang Zhao ${ }^{\text {a }}$, Guofu Wang, Yuanhua Chen \\ Guilin University of Aerospace Technology, Guilin 541004, China \\ azhw3721@qq.com
}

Keywords: Automotive applied talents, Resources, Curriculum system.

\begin{abstract}
From the aspects of the practical teaching conditions and the curriculum system, the reform of the training mode of automobile applied talents is discussed. This paper constructs a specialized course system for automobile industry oriented automobile market, strengthening the practice teaching link by relying on the school and social resources, forms a perfect theory and practice teaching system of applied automobile speciality, It provides a guarantee for the training of applied automotive professional talents.
\end{abstract}

\section{Introduction}

Based on the requirements of the training program for applied automotive professional talents, the following principles should be followed and based on the following principles[1-2]: Firstly, the type of school is a teaching type, that is to train talents as the fundamental task, and to actively carry out scientific research and scientific and technological services. Secondly, the level of school running is the undergraduate. Thirdly, the target of personnel training for the application type, that is to cultivate advanced applied talents with all-round development, innovation spirit and practice ability. What's more, Service orientation is based on Guilin, facing the whole province and serving the local social and economic development.

\section{Training Applied Automotive Professional Talents in the Rear of the Car Market}

In order to adapt to the basic requirements of the post car market for talent quality and ability, actively carrying out the reform of education and teaching, establishing a distinct training model for applied talents, Taking professional teaching reform as the core, practice teaching absorbs the latest achievements in social and technological development, and forms a practical teaching system combining basic practical skills and operative skills, professional skills and vocational skills. Forming a talent training system adapted to the requirements of the post market market, including personnel training mode, curriculum system, excellent course, excellent teaching material, teaching software and practical teaching base. As shown in Figure 1, this teaching system of this course is used as the main purpose and characteristic, which is both independent and interpenetrating. 


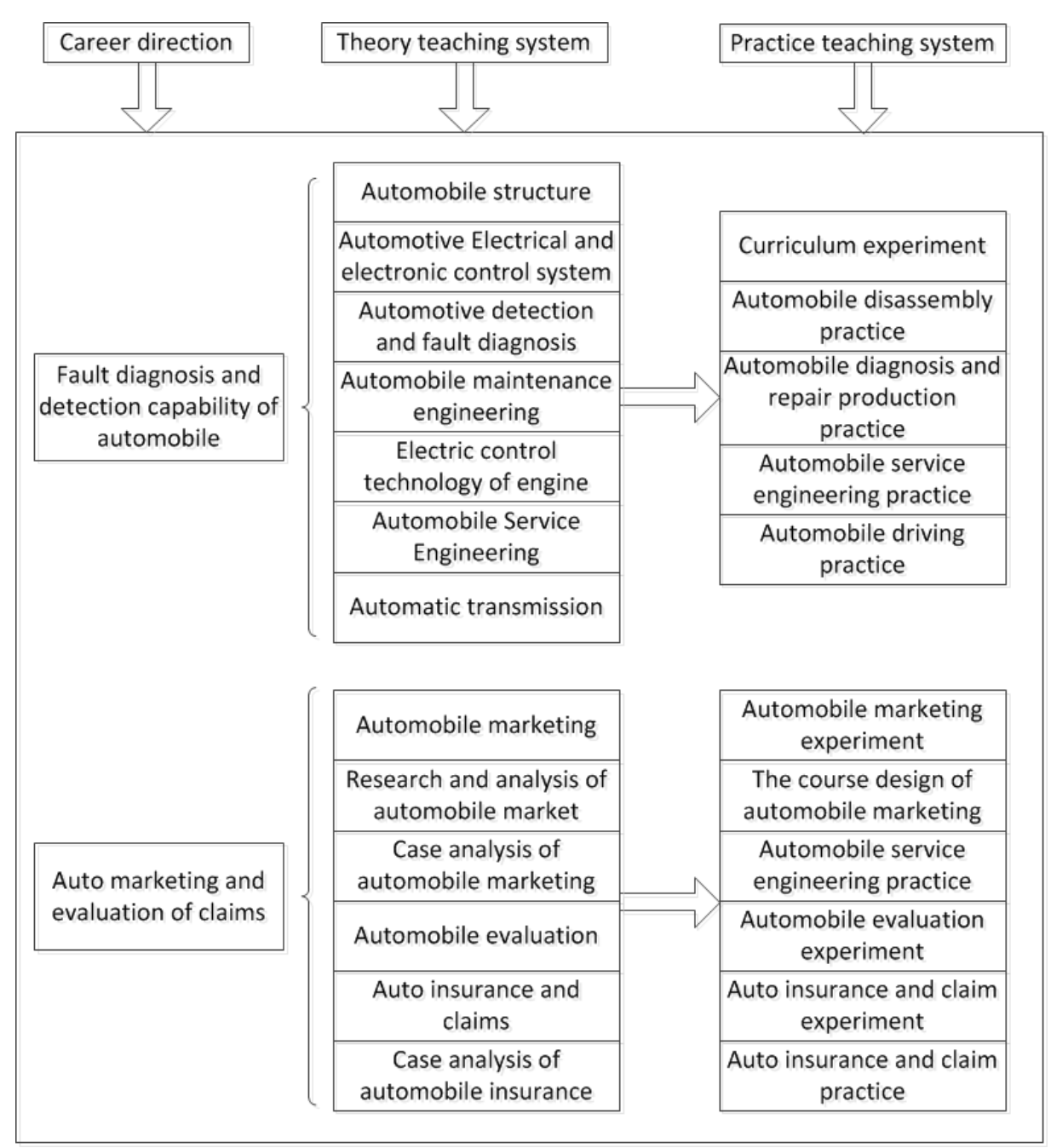

Fig.1 Professional ability and course teaching system of automobile applied specialty

\section{Relying on Schools and Social Resources to Cultivate Applied Automotive Professional Talents}

\subsection{Strengthening the Construction of the Basic Conditions for the Internship and Practical Training in School.}

Guilin University of Aerospace Technology has accumulated investment of more than 17 million yuan, the laboratory covers an area of nearly 6000 square meters, set up an engineering training center, 7 specialized laboratories, built a comprehensive vehicle engineering laboratory, major experimental equipment such as engine performance test bed, engine dynamometer and so on. The college has a national professional qualification training and identification workstation, which can carry out the national professional qualification identification work of automobile maintenance workers and automobile maintenance technicians.

\subsection{Making Full Use of Social Resources to Cultivate Talents.}

Through strengthening the cooperative education of production, school and research, exploring the diversified mode and way of cultivating applied talents, cultivating and exercising students' creative consciousness and practical ability [3]. The practice base is playing a more and more important role in guaranteeing teaching and improving the quality of applied talents. At present, the college has established 14 internship bases outside Guangxi Yuchai Machinery Co. Ltd., Guilin bus group etc.These outside intern practice bases have strong overall strength, advanced equipment and standard management, which can guarantee the quality of practice. In addition, it has appointed an enterprise expert to serve as an out of school instructor and instructs the students with the school teachers to coordinate and ensure the operation of the practice base. 


\section{The Construction of the Curriculum Structure System for the Training Mode of Automobile Applied Talents}

\subsection{The Construction of Talent Training Model}

In the formulation and application of automobile talents training plan process, combined with the training goal of automobile application and service field of applied talents, the construction of general education, professional education and quality development training system for combination of talents, to cultivate the automobile application and service field of applied talents and automobile occupation technical education teacher training target, in order to cultivate students' skills and comprehensive quality as the core of knowledge, ability and quality to develop the formation system, and established the "platform + module + ability" to expand the talents cultivating mode[4].

To cultivate students' ability and quality of the development is mainly reflected in strengthening students' basic skills training, so that students have more hands-on training opportunities; mastering and understanding but also continue to deepen the students' basic knowledge of the professional and basic skills, to cultivate the applied talents. To cultivate students' innovation ability, strengthen the training of personnel adaptability, make students grasp the basic technology is mainly engaged in scientific research and basic skills, through innovative practice, cultivate students' comprehensive ability of using knowledge, to enable students to keep the professional knowledge to practice, cultivate creative thinking and comprehensive ability to analyze and solve problems. The training program of automotive professionals has set up a practical link course aimed at developing basic skills and overall quality development: Automobile disassembly and assembly skills training, vehicle driving textual research training, automobile skills qualification examination, training, electronic process production, etc.

\subsection{Construction of a New Teaching System for Experimental Courses}

Change and update the concept of education, from classroom centered, teacher centered to extracurricular class combination, with students as the center and focus on the training of engineering practice ability, pay attention to students' personality development and innovation consciousness, strengthen the quality education and the cultivation of ability, flexible specialty direction. Actively explore new mode of teaching practice the teaching mode of application type automobile specialty strengthening classroom teaching with the practical course of combining the practice, constantly update the teaching concepts, practice teaching and theory teaching combined with the creative use of "three-in-one", "cooperative learning method based on practice" and "learning" and "teaching theory + practice teaching and innovation ability." the implementation of the examination form, flexible teaching method and modern teaching methods (multimedia classroom learning net, etc.), to strengthen the teaching practice teaching Interaction with learning has stimulated students' interest in learning, improved the practice teaching effect of automobile application, and formed a new teaching mode integrating theoretical teaching, practical skills training and innovative activities, so as to achieve the purpose of training applied and innovative talents.

\section{Summary}

The reform of training applied talents training mode of the automobile, from the optimization of talents, construct new mode of professional knowledge, ability and quality structure of the curriculum system of cultivating applied talents of automobile, optimizing curriculum system teaching content, practice teaching model applied in automobile specialty exploration of classroom instruction and practice course of new combination, and to strengthen teachers team construction and practice are discussed, and based on the 2016 and 2017 grade professional training program was revised, achieved good effect, the quality of personnel training has been improved. Many students in the implementation of the reform in the car, gradually revealed application of talents training and the actual effect of the reform, the enthusiasm of the students has been improved, the index of the quality of teaching, such as college English Four (six) pass rate, pass rate, computer grade postgraduate rate, certificates obtained rate have been improved constantly. The training mode of automobile applied talents has been recognized by the society gradually. The social employing unit welcomed the training 
of automobile professionals in our school, and was very willing to accept corresponding professional graduates, reflecting the graduates generally well.

\section{Acknowledgments}

This work is carried out with the support of the research project of teaching reform of Vocational Education in Guangxi in 2016. The construction and practice of the curriculum system of automobile inspection and maintenance specialty based on the cultivation of post professional ability (NO.GXGZJG2016A058).

\section{References}

[1]. Zhang X. Thoughts of the Applied Talents' Career Aspiration Education [J]. Sichuan University of Arts \& Science Journal, 2017.

[2]. Guo S, Qiujun L U, Zhao L, et al. Practice and exploration of applied talents training for local undergraduate universities[J]. Journal of Heilongjiang Institute of Technology, 2017.

[3]. Wang L Q. Study on the Effective Path to Improve the Ability of Innovation and Entrepreneurship of College Students [J]. Education Teaching Forum, 2017.

[4]. Xia S. The Construction of Talents Training Mode in the Teaching of Vehicle Operation and Maintenance [J]. Modern Manufacturing Technology \& Equipment, 2017. 